Doerte Bischoff und Susanne Komfort-Hein Literatur und Exil 



\section{Literatur und Exil}

Neue Perspektiven

Herausgegeben von

Doerte Bischoff und Susanne Komfort-Hein

\section{DE GRUYTER}


ISBN 978-3-11-028564-2

e-ISBN 978-3-11-028574-1

\section{Library of Congress Cataloging-in-Publication Data}

A CIP catalog record for this book has been applied for at the Library of Congress.

\section{Bibliografische Information der Deutschen Nationalbibliothek}

Die Deutsche Nationalbibliothek verzeichnet diese Publikation in der Deutschen Nationalbibliografie; detaillierte bibliografische Daten sind im Internet über http://dnb.dnb.de abrufbar.

(C) 2013 Walter de Gruyter GmbH, Berlin/Boston

Satz: Johanna Boy, Brennberg

Druck und Bindung: Hubert \& Co. GmbH \& Co. KG, Göttingen

$\infty$ Gedruckt auf säurefreiem Papier

Printed in Germany

www.degruyter.com 